\title{
Employee Satisfaction and Theft: Testing Climate Perceptions as a Mediator
}

\author{
JOHN T. KULAS \\ St. Cloud State University \\ JOANNE E. MCINNERNEY \\ Ohio Savings Bank \\ RACHEL FRAUTSCHY DEMUTH \\ Career Momentum, Inc. \\ VICTORIA JADWINSKI \\ St. Cloud State University
}

\begin{abstract}
Employee theft of both property and time is an expensive and pervasive problem for American organizations. One antecedent of theft behaviors is employee dissatisfaction, but not all dissatisfied employees engage in withdrawal or theft behaviors. The authors tested a model of theft behavior by using an organization's climate for theft as an explanatory mechanism. They found that dissatisfaction influenced employee theft behaviors through the intermediary influence of employees' individual perceptions of the organization's climate for theft. The authors encourage organizations to pay attention to such climate elements and take action to alter employee perceptions if they reflect permissive attitudes toward theft.
\end{abstract}

Keywords: employee dissatisfaction, employee theft, organizational climate

EMPLOYEE THEFT IS A PERVASIVE AND EXPENSIVE PROBLEM for organizations; it has been reported as 10 times as costly as America's street crime (Greenberg, 1997). The cost of property theft alone has been estimated to be $\$ 40$ billion per year (Shapiro, Trevino, \& Victor, 1995), and about one third of employees admit to stealing from their employers (Kamp \& Brooks, 1991). Employee deviance, a broader categorization of antiproductive behavior that subsumes theft, is prevalent and widely studied in many industries, including retail sales, food service, manufacturing, and health care (Hollinger \& Clark, 1983b; Jones \& Terris, 1985). Deviance costs have been estimated to reach $\$ 200$ billion

Address correspondence to John T. Kulas, Assistant Professor, Department of Psychology, Whitney 303, St. Cloud State University, St. Cloud, MN 56301, USA; jtkulas@stcloudstate.edu (e-mail). 
each year nationwide and to be responsible for $30 \%$ of small business failures (Murphy, 1993).

It is clear that employee deviance is a costly burden on organizations, but the antecedents and processes through which such deviant behavior is manifest are not as apparent. Many researchers studying theft use frustration- or aggression-based social-psychological frameworks that specify attitudinal-behavioral links (Neuman \& Baron, 1997; Spector, 1978, 1997). In this study, we specified a similar attitude-behavior association but added a possible contextual mediating influence: organizational climate perceptions. Environmental and cultural components are often considered as third variable moderators in organizational research (Byrne, Stoner, Thompson, \& Hochwarter, 2005; Elenkov \& Manev, 2005). However, we posited that individual climate for theft perceptions act as an explanatory mechanism through which the relation between job satisfaction or dissatisfaction and employee theft is manifest.

\section{Employee Deviance}

Robinson and Bennett (1995) used a broad category of deviant workplace behaviors within which theft may be investigated. Two dimensions of deviance, ranging from minor (m) to serious (s) and organizational (o) to interpersonal (i), can be combined to form four counterproductive behavior categories: property deviance $(\mathrm{s}, \mathrm{o})$, production deviance $(\mathrm{m}, \mathrm{o})$, political deviance $(\mathrm{m}, \mathrm{i})$, and personal aggression $(\mathrm{s}, \mathrm{i})$. In this study, we focused on the model dimensions of serious and minor incidents of organizational deviance, or production deviance and property deviance. These categories subsume specific behaviors of time theft (production deviance) and physical theft (property deviance).

Property deviance includes employee behaviors that involve the unauthorized taking, control, or transfer of money or property of the formal work organization by an employee, either for the employee's own use or for sale to another, during the course of occupational activity (Greenberg, 1997; Hollinger \& Clark, 1983b). It includes behaviors such as misuse of employee discounts; taking merchandise, supplies, or information for personal use or sale; filching money or production materials; and falsifying time records. The boundaries of employee theft as defined here do not include theft of coworker property.

Production deviance includes what has been referred to as work withdrawal behavior. These behaviors can take the form of reduced productivity, increased absenteeism and tardiness, low job involvement, and low organizational commitment (Hanisch, Hulin, \& Roznowski, 1998). The production deviance construct also includes behaviors such as leaving work early and taking unauthorized breaks (Blau, 1998). Individuals engage in these behaviors to maximize or maintain social and organizational roles. When these motives conflict with formal job responsibilities or when employees are dissatisfied, individuals minimize time spent on formal job tasks (Hanisch \& Hulin, 1991). Production deviance behaviors that result in the 
reduction of time working (e.g. tardiness, absenteeism, abuse of sick time, unauthorized breaks, socializing, loitering) are considered to be time theft.

\section{Satisfaction and Theft}

Many researchers use attitudes such as dissatisfaction to predict deviant employee behavior (Bolin \& Heatherly, 2001). According to Murphy (1993), satisfied individuals tend to exhibit prosocial behaviors, whereas unsatisfied individuals tend to commit acts of property and production deviance. Hanisch and Hulin's (1991) definition of work withdrawal assumes that dissatisfaction is the catalyst for behaviors such as time theft. Individuals involved in employee theft also are often involved in other deviant behaviors (Murphy). Hollinger and Clark (1983b) found relations between job dissatisfaction and property deviance among samples of retail and hospital employees, but not manufacturing employees. They also found a significant relation between job dissatisfaction and production deviance (i.e., work withdrawal or time theft) in all three industries.

Differences between the strength of relation between satisfaction and property deviance and satisfaction and production deviance could occur because of perceived differences in organizational sanctions for these behaviors. Johns (1998) suggested that work context may constrain the exhibition of one withdrawal behavior while allowing the expression of another theoretically related behavior. Hanisch et al. (1998) suggested that the set of withdrawal behaviors that manifests as a result of negative job attitudes is a function of the situation and job constraints. These sanctions and constraints would be communicated by an organization's climate for theft.

\section{Climate for Theft}

According to Murphy (1993), many researchers have acknowledged the importance of situational factors to employee deviance, but few have examined this relationship. Boye and Jones (1997) suggested that the effect of specific aspects of climate for theft should be examined. Climate for theft includes the opportunity to steal and the perceived and communicated norms of the organization, management, and work group. Included in these norms is the attitude toward theft, perceived extent of coworker and management theft, perceived certainty of sanctions for theft, and perceived severity of sanctions for theft. Hollinger and Clark (1983a) examined the conditions under which employees commit theft. They found that the perception of certainty and severity of organizational sanctions were related to employee theft. The perceived certainty of sanctions had a stronger relation with theft than did the perceived severity of sanctions. The least theft occurred in situations in which sanctions were perceived as severe and certain.

Greenberg (1997) suggested that norms, unwritten rules that guide behavior and contribute to an organization's climate, often condone or encourage employee 
theft. For example, managers who engage in theft may establish a norm that such behavior is tolerated. Managers also may encourage theft by allowing employees to use equipment and materials for personal use or rewarding extra behaviors with free or highly discounted products (Greenberg). If steal-friendly norms have been established and the organizational climate is perceived as permissive to such actions, employees may steal to fit in or get along with their coworkers. Consistent with this climate-based influence, Hollinger and Clark (1983b) found that the influence of coworker attitudes on theft behavior was stronger than that of management sanctions or employee fear of reprisal.

In this study, we explored a subset of the dimensions that may contribute to an organizational climate for theft: perceptions of ease of theft, likelihood of being caught stealing, and perceptions of coworker permissiveness regarding theft. Therefore, we incorporated theft opportunity and perceived theft-related norms of the organization (including perceived coworker attitudes) but did not directly assess the perception that consequences will be meted out if one is caught stealing.

\section{Summary and Hypothesis}

Attitudinal organizational researchers have found that dissatisfied individuals are more likely than are satisfied individuals to engage in theft behaviors (Hanisch \& Hulin, 1991; Murphy, 1993). Climate researchers have found that theft is more prevalent when organizational, management, and coworker attitudes support theft (Greenberg, 1997; Hollinger \& Clark, 1983b). The mechanism through which we proposed that satisfaction affects theft behavior is norm- and climate-based. We hypothesized that climate for theft would mediate the relations between satisfaction and theft and satisfaction and time theft (see Figure 1).

\section{Method}

\section{Participants}

We delivered 2,047 organizational surveys to employees at 19 different supermarket companies in a three-phase process. We invited no more than two employees per store to participate. First, we sent employees a letter informing them of the study, then the surveys with dollar incentives, and then second copies of the survey. This survey process yielded a return rate of $43 \%$ (1,004 of 2,047). Of the 1,004 returned surveys, we discarded 155 surveys because the respondents had answered fewer than $90 \%$ of the questions, did not currently work in the supermarket industry, or had less than 2 months of tenure at their organizations.

Of the final sample respondents, 33\% self-identified as managers and 67\% self-identified as entry-level employees. Forty-eight percent were men, and 52\% were women. Sixty-one percent were employed at supermarket stores in an urban location, $29 \%$ worked in city suburbs, and $10 \%$ worked in rural areas. More than 


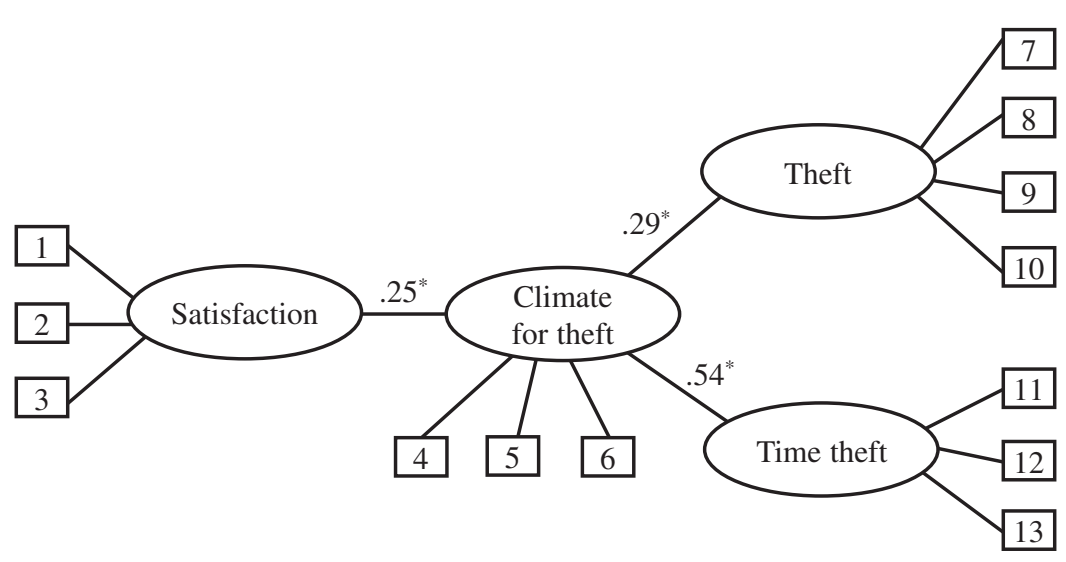

FIGURE 1. The fully mediated theft model. $\chi^{2}(58, N=847)=176$; Root mean square error of approximation $=.049$. ${ }^{*} p<.01$. Numbers $1-11$ refer to employee survey questions.

half $(56 \%)$ of participants worked the day shift, $27 \%$ worked the evening shift, and $17 \%$ worked the night shift.

\section{Materials}

We used the Employee Perceptions Survey (National Computer Systems, 1998) in this study. It contains 74 questions that address (a) demographic information such as age, gender, and tenure with the company and (b) desirable workplace behaviors and counterproductive employee behaviors such as theft, sick-day abuse, and substance use. We used a Q-sort methodology to identify which items represented the constructs of satisfaction, climate for theft, theft, and time theft. Items chosen from this process are shown in Table 1.

The climate for theft items include perceptions of ease of theft, likelihood of being caught stealing, and perceptions of coworker permissiveness regarding theft. Although these items do not reflect the entire spectrum of dimensions contributing to perceptions of a permissive theft climate, they are important elements of the general construct (Bolin \& Heatherly, 2001).

Job satisfaction measures typically focus on either facets of satisfaction, including pay, supervision, or coworkers (e.g., Smith, Kendall, \& Hulin, 1969), or global satisfaction (Campbell \& Campbell, 2003). Our items ("All in all, I am satisfied with my present job"; "I would recommend this job to a friend"; and "I am satisfied with my company") reflect global, rather than facet, job satisfaction because we were interested in studying general attitudes regarding one's job. 
TABLE 1. Employee Survey Items Retained for Analysis

\begin{tabular}{|c|c|c|}
\hline Construct & Number & Item \\
\hline \multirow[t]{3}{*}{ Satisfaction } & 1 & All in all, I am satisfied with my present job. ${ }^{a}$ \\
\hline & 2 & I would recommend this job to a friend. ${ }^{\mathrm{a}}$ \\
\hline & 3 & I am satisfied with my company. ${ }^{\text {a }}$ \\
\hline \multirow[t]{3}{*}{ Climate for theft } & 4 & $\begin{array}{l}\text { I could easily take money, merchandise, or } \\
\text { property from my employer any time I want. }\end{array}$ \\
\hline & 5 & $\begin{array}{l}\text { I would be caught if I took something from } \\
\text { my employer. }\end{array}$ \\
\hline & 6 & $\begin{array}{l}\text { My coworkers feel that taking company } \\
\text { merchandise or property without permission } \\
\text { is acceptable. }{ }^{\text {a }}\end{array}$ \\
\hline \multirow[t]{4}{*}{ Theft } & 7 & Used employee discount privileges for friends? \\
\hline & 8 & $\begin{array}{l}\text { Taken company supplies or equipment for } \\
\text { personal use? }^{\text {b }}\end{array}$ \\
\hline & 9 & $\begin{array}{l}\text { Taken merchandise or equipment from your } \\
\text { employer without permission? }{ }^{\mathrm{b}}\end{array}$ \\
\hline & 10 & $\begin{array}{l}\text { Taken money from your employer without } \\
\text { permission? }^{\text {b }}\end{array}$ \\
\hline \multirow[t]{3}{*}{ Time theft } & 11 & Come to work late without permission $?^{\mathrm{b}}$ \\
\hline & 12 & Left work early without permission?b \\
\hline & 13 & Faked an illness and called in sick? ${ }^{\mathrm{b}}$ \\
\hline
\end{tabular}

Note. Items copyright 1998 by National Computer Systems. No unauthorized use of these items is permitted.

aThe item began with the stem, "Please mark how much you agree or disagree with the following statements," with a 6-point Likert-type response scale ranging from 1 (strongly disagree) to 6 (strongly agree). ${ }^{\mathrm{b}}$ The item began with the stem, "How often during the last 6 months have you ..." Participants answered on a 5-point Likert-type scale ranging from 1 (very often) to 5 (never).

\section{Procedure}

To test the proposed model, we used LISREL 8.3 (Jöreskog \& Sörbom, 1993) with a maximum-likelihood estimation procedure. Because of the convenience sample and post hoc operationalization of constructs, we used a twostep process (Anderson \& Gerbing, 1988). We tested the measurement model and then the full model, including both structural and measurement model portions. Using this process optimized the measurement of constructs before considering structural paths, thereby increasing our ability to detect important structural relations. We used structural equation modeling (instead of, for example, multiple regression) because this approach reduces measurement error through the incorporation of multiple indicators per construct, allows for the simultaneous estimation of model parameters, and has relaxed assumptions with regard to multicollinearity. 


\section{Results}

Means, standard deviations, and correlations of study items are shown in Table 2.

\section{Confirmatory Factor Analysis}

Confirmatory factor analysis (CFA) tests a priori hypotheses of specific relations between latent constructs and observed variables (i.e., the measurement model). Table 3 shows model chi square (Satorra \& Bentler, 1994), root mean square error of estimation (RMSEA), non-normed fit index (NNFI; Tucker \& Lewis, 1973), and comparative fit index (CFI; Bentler, 1990). Lower chi square values indicate a better match of the implied covariance matrix to the actual covariance matrix. RMSEA is not sensitive to sample size, and a value under .05 is indicative of a good fit. NNFI and CFI range from 0 to 1 , with values above .90 indicating a good fit (Hoyle, 1995).

As the Q-sort suggested, the fit indexes revealed a moderately good fit of the data with a low chi square, a RMSEA nearly at the desirable level, and nearly desirable levels for NNFI and CFI indexes. On the basis of practical considerations (i.e., similarity of items not attributable to the specified construct) and modification indexes, we freed some error parameters within constructs: the paths between the first and second items for climate for theft and between the first and second, first and third, and second and fourth items for theft. We freed these error terms in all remaining analyses. The item factor loadings of this modified CFA for each of the four constructs and the corresponding error terms are summarized in Table 4, and covariances between factors are shown in Table 5. Squared multiple correlations for each item ranged from .17 to .57 , indicating that the four latent constructs accounted for $17-57 \%$ of variance.

\section{Partially Mediated Model}

Before testing for mediation, we established significant direct paths between the independent variable (IV) of satisfaction and both the mediator (i.e., climate for theft) and the dependent variables (DVs). Results of these direct models are summarized in Table 3. In this instance, we were primarily interested not in the overall fit, but in the parameter estimates linking satisfaction to the mediator (first direct model) and dependent variables (second direct model). The parameter estimate between satisfaction and climate for theft was $\gamma=.38, p<.01$. The parameter estimate between satisfaction and theft was $\gamma=.06, p<.01$ and between satisfaction and time theft was $\gamma=.16, p<.01$. Having established significant paths between the IV and both the mediator and DVs, we examined the fit of a partially mediated model in which (a) satisfaction and (b) theft and time theft have both direct and indirect (i.e., through climate for theft) relations. The 
TABLE 2. Means, Standard Deviations, and Correlations Among Survey Items

\begin{tabular}{|c|c|c|}
\hline Item & $M$ & $S D$ \\
\hline 1. All in all, I am satisfied with my present job. ${ }^{a}$ & 3.7 & 1.27 \\
\hline 2. I would recommend this job to a friend. ${ }^{\mathrm{a}}$ & 3.7 & 1.36 \\
\hline 3. I am satisfied with my company. ${ }^{\text {a }}$ & 3.6 & 1.29 \\
\hline $\begin{array}{l}\text { 4. I could easily take money, merchandise, or property from } \\
\text { my employer any time I want. }{ }^{\mathrm{a}}\end{array}$ & 4.6 & 1.73 \\
\hline 5. I would be caught if I took something from my employer. ${ }^{a}$ & 3.8 & 1.37 \\
\hline $\begin{array}{l}\text { 6. My coworkers feel that taking company merchandise or } \\
\text { property without permission is acceptable. }\end{array}$ & 5.0 & 1.15 \\
\hline 7. Used employee discount privileges for friends? ${ }^{b}$ & 4.9 & 0.44 \\
\hline 8. Taken company supplies or equipment for personal use? ${ }^{\mathrm{b}}$ & 4.8 & 0.47 \\
\hline $\begin{array}{l}\text { 9. Taken merchandise or equipment from your employer } \\
\text { without permission? }^{\mathrm{b}}\end{array}$ & 4.9 & 0.41 \\
\hline 10. Taken money from your employer without permission? ${ }^{b}$ & 5.0 & 0.17 \\
\hline 11. Come to work late without permission? ${ }^{\mathrm{b}}$ & 4.4 & 0.79 \\
\hline 12. Left work early without permission? ${ }^{\mathrm{b}}$ & 4.8 & 0.52 \\
\hline 13. Faked an illness and called in sick? ${ }^{\mathrm{b}}$ & 4.7 & 0.62 \\
\hline
\end{tabular}

Note. $N=847$. Significant correlations are in bold type $(p<.05)$. Items copyright 1998 by National Computer Systems. No unauthorized use of these items is permitted.

aThe item began with the stem,"Please mark how much you agree or disagree with the following statements," with a 6-point Likert-type response scale ranging from 1 (strongly disagree) to 6 (strongly agree). ${ }^{\mathrm{b}}$ The item began with the stem, "How often during the last 6 months have you ..." Participants answered on a 5-point Likert-type scale ranging from 1 (very often) to 5 (never).

overall fit indexes of the partially mediated model are shown in Table 4. This model provided good fit with a low chi square, a RMSEA below .05, and NNFI and CFI indexes above .9. An important finding was that the significant direct paths in the direct model between satisfaction and the DVs (i.e., theft and time theft) became insignificant in this partially mediated model (satisfaction to theft: $\gamma=-.08, p=n s$; satisfaction to time theft: $\gamma=-.09, p=n s)$.

\section{Fully Mediated Model}

As we hypothesized, the fully mediated model fit the data well, as indicated by the low $\chi^{2}$, the RMSEA below .05, and the NNFI and CFI indexes above .9 (see Table 2). The change in $\chi^{2}$ between this fully mediated model and the partially mediated was not significant. In addition, the RMSEA of the partially mediated model was included in the RMSEA confidence interval of the fully mediated model. Both of these comparative statistics indicate that the fit of this model was not significantly worse than was the fit of the nested, partially mediated model, suggesting that the fully mediated model best fits the data (see Figure 1). 


\begin{tabular}{|c|c|c|c|c|c|c|c|c|c|c|c|c|}
\hline 1 & 2 & 3 & 4 & 5 & 6 & 7 & 8 & 9 & 10 & 11 & 12 & 13 \\
\hline- & & & & & & & & & & & & \\
\hline .33 & - & & & & & & & & & & & \\
\hline .46 & .46 & - & & & & & & & & & & \\
\hline .14 & .09 & .07 & - & & & & & & & & & \\
\hline .13 & .13 & .13 & .40 & - & & & & & & & & \\
\hline .15 & .09 & .11 & .28 & .22 & - & & & & & & & \\
\hline .10 & .09 & .07 & .10 & .10 & .14 & - & & & & & & \\
\hline .15 & .12 & .12 & .14 & .15 & .17 & .33 & - & & & & & \\
\hline .18 & .07 & .01 & .20 & .20 & .19 & .31 & .37 & - & & & & \\
\hline .00 & -.02 & -.07 & .07 & .07 & .10 & .23 & .10 & .35 & - & & & \\
\hline .12 & .07 & .05 & .07 & .10 & .18 & .19 & .19 & .19 & .08 & - & & \\
\hline .05 & .06 & .01 & .13 & .08 & .13 & .18 & .25 & .21 & .12 & .30 & - & \\
\hline .14 & .10 & .12 & .07 & .04 & .17 & .29 & .30 & .21 & .11 & .37 & .22 & - \\
\hline
\end{tabular}

TABLE 3. Comparison of Models for Testing the Mediation of Climate for Theft Between Satisfaction and Theft $(N=847)$

\begin{tabular}{|c|c|c|c|c|c|c|c|}
\hline Model & $\chi^{2}$ & $d f$ & $\Delta \chi^{2}$ & $\Delta d f$ & RMSEA & NNFI & CFI \\
\hline Measurement model & 190 & 59 & - & - & .052 & .89 & .92 \\
\hline $\begin{array}{l}\text { Modified measurement model } \\
\text { Direct model }\end{array}$ & 137 & 55 & - & - & .042 & .93 & .95 \\
\hline $\begin{array}{l}\text { Mediator on independent } \\
\text { variable }\end{array}$ & 16 & 7 & - & - & .040 & .97 & .99 \\
\hline $\begin{array}{l}\text { Dependent variable on } \\
\text { independent variable }\end{array}$ & 224 & 30 & - & - & .085 & .77 & .84 \\
\hline Partial mediation & 169 & 56 & - & - & .048 & .90 & .93 \\
\hline Full mediation & 176 & 58 & 7 & 2 & .049 & .90 & .92 \\
\hline
\end{tabular}

Note. RMSEA = root mean square error of approximation; $\mathrm{NNFI}=$ non-normed fit index; $\mathrm{CFI}=$ comparative fit index; $d f=$ degrees of freedom. All $\chi^{2}$ are significant at $p<.05$. 
TABLE 4. Modified Confirmatory Factor Analysis: Standardized Loadings from the Lambda Chi and Theta Delta Matrixes

\begin{tabular}{lllll}
\hline \hline Item & Sat & CFT Theft Time $\Theta_{\delta}$
\end{tabular}

1. All in all, I am satisfied with my present job. ${ }^{\mathrm{a}}$

2. I would recommend this job to a friend. ${ }^{\mathrm{a}}$

3. I am satisfied with my company. ${ }^{\mathrm{a}}$

4. I could easily take money, merchandise, or property from my employer any time I want. ${ }^{\mathrm{a}}$

5. I would be caught if I took something from my employer. ${ }^{\mathrm{a}}$

6. My coworkers feel that taking company merchandise or property without permisson is acceptable. ${ }^{a}$

7. Used employee discount privileges for friends? ${ }^{\mathrm{b}}$

8. Taken company supplies or equipment for personal use? ${ }^{\mathrm{b}}$

9. Taken merchandise or equipment from your employer without permission? ${ }^{\mathrm{b}}$

10. Taken money from your employer without permission? ${ }^{\mathrm{b}}$

11. Come to work late without permission? ${ }^{\mathrm{b}}$

12. Left work early without permission?

Note. All factor loadings are significant at $p<.01$. Sat $=$ satisfaction; CFT $=$ climate for theft; Theft $=$ cash and property theft; Time $=$ time theft (i.e., sick day abuse, absenteeism).

aThe item began with the stem,"Please mark how much you agree or disagree with the following statements." bThe item began with the stem, "How often during the last 6 months have you ...."

\section{Discussion}

In this study, we replicated the established finding that dissatisfied employees engage in more theft behaviors than do their relatively more satisfied coworkers. We also found that dissatisfaction was associated with theft-permissive climate perceptions, and these climate perceptions were predictive of self-reported theft of time and property. Across constructs, we scored analyzed items so that high item responses indicated desirable organizational attitudes and behaviors (high satisfaction, low climate perceptions, and low theft behaviors). We fit this model in an attempt to provide organizational practitioners a possible explana- 
TABLE 5. Fully Mediated Theft Model: Factor Variance (in Parentheses on the Diagonal) and Covariance

\begin{tabular}{lcccc}
\hline \hline Item & 1 & 2 & 3 & 4 \\
\hline 1. Satisfaction & $(0.67)$ & & & \\
2. Climate for theft & 0.27 & $(1.29)$ & & \\
3. Theft & 0.05 & 0.25 & $(0.11)$ & \\
4. Time theft & 0.09 & 0.44 & 0.09 & $(0.45)$
\end{tabular}

Note. All correlations are significant at $p<.01$.

tory mechanism for the satisfaction-theft relation. Overall, results support the hypothesized fully mediated model. Climate for theft fully explained the relations between dissatisfaction and theft and dissatisfaction and time theft.

\section{Implications}

Because of high organizational losses from employee theft, this research has important implications for organizations. Full mediation suggests that the relation between dissatisfaction and theft occurs through climate perceptions, although the climate construct we used lacks some important climate dimensions, such as likelihood of retribution for theft. Satisfaction is a common focus of intervention within organizations. If employee theft is an outcome of concern or a problem area for the organization, practitioners should also focus on the attitudes and perceptions employees have regarding the permissibility of theft at the workplace.

If climate perceptions are less than ideal, organizations can take action to change the climate for theft. Boye and Jones (1997) suggested that climate can be changed directly, by addressing employee perceptions of organizational characteristics, or indirectly, by changing objective characteristics of the working environment (i.e., physical opportunity for theft, such as presence or absence of security measures). Boye and Jones outlined various methods of modifying the climate for theft and counterproductive behavior. In addition to targeting employee satisfaction levels, this could be useful to organizations' theft-prevention programs.

Climate for theft is an important variable to study in organizational settings. Climate researchers should focus on whether these perceptions, as one climate dimension, pervade other climate dimensions (i.e., Is climate for theft orthogonal or correlated with general climate perceptions?). The relation between climate for theft perceptions and overall attitude toward the organization has important implications for the focus of interventions (e.g., If one climate dimension is targeted, are other climate dimensions impacted?). Climate for theft may be 
associated with other outcomes of interest to organizations, such as sabotage, turnover, or general performance, and future researchers can help determine the most effective ways for organizations to change their climate for theft to reduce overall theft costs as well as the other potential outcomes.

\section{Limitations and Future Research}

We gathered theft estimates with a self-report measure rather than by analyzing actual organizational losses. Kamp and Brooks (1991) suggested that self-report of theft may be conservative because of socially desirable response tendencies. Ideally, this study should be replicated using actual organizational losses. There also seems to be little consistency of the definitions of theft and climate for theft constructs among researchers.

The climate for theft dimensions included in this study were limited to perceptions of ease of theft, likelihood of being caught stealing, and estimates of coworkers' permissiveness regarding theft. Perceptions of consequences of theft were not included. However, this dimension was related to theft behavior in previous studies (e.g., Hollinger \& Clark, 1983a). Although theft is reduced by severe and certain sanctions, our results suggest that other climate-related attitudes beyond fear of consequences are important in the prediction of employee theft. Future researchers should use standard conceptual definitions and comparative operational measurement of these constructs. Robinson and Bennett's (1995) framework is a simple but sufficient organizing framework within which conceptual deviance behaviors can be comparatively investigated.

The model used in this context may seem perplexing, but given the level of analysis (individual perceptions), we found that a mediational model was most appropriate. Future researchers should assess cultural or climate-related elements at the organizational level and test moderated models of satisfaction and theft, determining, for example, if this association is stronger within organizations that possess permissive cultures than within relatively less permissive organizational cultures.

Our results establish a relation between satisfaction and climate perceptions and the subsequent impact on theft behaviors. Although we examined only dissatisfaction as an exogenous predictor, other individual difference variables such as age, gender, and propensity to steal have been related to employee theft (Hollinger \& Clark, 1983a; Greenberg, 1997; Murphy, 1993). Justice perceptions are other potential mediators or moderators (Shapiro et al., 1995). With an emerging body of research establishing relations between predictors, moderators and mediators, and theft, researchers should posit and test more comprehensive and further explanatory models of theft. Researchers also should identify differences and similarities in theft prediction among different industries (i.e., manufacturing vs. service) and samples (i.e., blue- vs. white-collar employees). 


\section{REFERENCES}

Anderson, J. C., \& Gerbing, D. W. (1988). Structural equation modeling in practice: A review and recommended two-step approach. Psychological Bulletin, 103, 411-423.

Bentler, P. M. (1990). Comparative fit indices in structural models. Psychological Bulletin, 107, 238-246.

Blau, G. (1998). On the aggregation of individual withdrawal behaviors into larger multiitem constructs. Journal of Organizational Behavior, 19, 437-451.

Bolin, A., \& Heatherly, L. (2001). Predictors of employee deviance: The relationship between bad attitudes and bad behavior. Journal of Business and Psychology, 15, 405-418.

Boye, M. W., \& Jones, J. W. (1997). Organizational culture and employee counterproductivity. In R. Giacalone \& J. Greenberg (Eds.), Antisocial behavior in organizations (pp. 172-184). Thousand Oaks, CA: Sage.

Byrne, Z. S., Stoner, J., Thompson, K. R., \& Hochwarter, W. (2005). The interactive effects of conscientiousness, work effort, and psychological climate on job performance. Journal of Vocational Behavior, 66, 326-338.

Campbell, D. J., \& Campbell, K. M. (2003). Global versus facet predictors of intention to quit: Differences in a sample of male and female Singaporean managers and non-managers. International Journal of Human Resource Management, 14, 1152-1177.

Elenkov, D. S., \& Manev, I. M. (2005). Top management leadership and influence on innovation: Theory of sociocultural context. Journal of Management, 31, 381-402.

Greenberg, J. (1997). Managing the social determinants of employee theft. In R. Giacalone \& J. Greenberg (Eds.), Antisocial behavior in organizations (pp. 85-108). Thousand Oaks, CA: Sage.

Hanisch, K. A., \& Hulin, C. L. (1991). General attitudes and organizational withdrawal: An evaluation of a causal model. Journal of Vocational Behavior, 39, 110-128.

Hanisch, K. A., Hulin, C. L., \& Roznowski, M. (1998). The importance of individuals' repertoires of behaviors: The scientific appropriateness of studying multiple behaviors and general attitudes. Journal of Organizational Behavior, 19, 463-480.

Hollinger, R. C., \& Clark, J. P. (1983a). Deterrence in the workplace: Perceived certainty, perceived severity, and employee theft. Social Forces, 62, 398-418.

Hollinger, R. C., \& Clark, J. P. (1983b). Theft by employees. Lexington, MA: Lexington Books.

Hoyle, R. H. (1995). Structural equation modeling: Concepts, issues, and applications. Thousand Oaks, CA: Sage.

Johns, G. (1998). Aggregation or aggravation? The relative merits of a broad withdrawal construct. Journal of Organizational Behavior, 19, 453-462.

Jones, J. W., \& Terris, W. (1985). Screening employment applicants for attitudes towards theft: Three quasi-experimental studies. International Journal of Management, 2(3), $62-75$.

Jöreskog, K. G., \& Sörbom, D. (1993). LISREL 8 user's reference guide (1st ed.). Chicago: Scientific Software.

Kamp, J., \& Brooks, P. (1991). Perceived organizational climate and employee counterproductivity. Journal of Business and Psychology, 5, 447-458.

Murphy, K. R. (1993). Honesty in the workplace. Pacific Grove, CA: Brooks Cole.

National Computer Systems. (1998). Employee perceptions survey. Rosemont, IL: Author.

Neuman, J. H., \& Baron, R. A. (1997). Aggression in the workplace. In R. A. Giacalone \& J. Greenberg (Eds.), Antisocial behavior in organizations (pp. 37-67). Thousand Oaks, CA: Sage.

Robinson, S. L., \& Bennett, R. J. (1995). A typology of deviant workplace behaviors: A 
multidimensional scaling study. Academy of Management Journal, 38, 555-572.

Satorra, A., \& Bentler, P. M. (1994). Corrections to test statistic and standard errors in covariance structure analysis. In A. Von Eye \& C. C. Clogg (Eds.), Analysis of latent variables in developmental research (pp. 399-419). Newbury Park, CA: Sage.

Shapiro, D. L., Trevino, L. K., \& Victor, B. (1995). Correlates of employee theft: A multi-dimensional justice perspective. International Journal of Conflict Management, 6, 404-414.

Smith, P. C., Kendall, L. M., \& Hulin, C. L. (1969). The measurement of satisfaction in work and retirement. Chicago: Rand McNally.

Spector, P. E. (1978). Organizational frustration: A model and review of the literature. Personnel Psychology, 31, 815-829.

Spector, P. E. (1997). The role of frustration in antisocial behavior. In R. A. Giacalone \& J. Greenberg (Eds.), Antisocial behavior in organizations (pp. 1-17). Thousand Oaks, CA: Sage.

Tucker, L. R., \& Lewis, C. (1973). A reliability coefficient for maximum likelihood factor analysis. Psychometrika, 38, 1-10.

Original manuscript received November 10, 2005

Final version accepted November 14, 2006 
Copyright of Journal of Psychology is the property of Heldref Publications and its content may not be copied or emailed to multiple sites or posted to a listserv without the copyright holder's express written permission. However, users may print, download, or email articles for individual use. 